\title{
Response of Rice Nitrogen Physiology to High Nighttime Temperature during Vegetative Stage
}

\author{
Song Chen, Xiaoguo Zhang, Xia Zhao, Danying Wang, Chunmei Xu, \\ Chenglin Ji, and Xiufu Zhang \\ China National Rice Research Institute, Chinese Academy of Agricultural Sciences, Hangzhou, Zhejiang 310006, China \\ Correspondence should be addressed to Xiufu Zhang; xzhang169@sohu.com
}

Received 24 June 2013; Accepted 13 July 2013

Academic Editors: R. Inoue and V. Shlyonsky

Copyright (c) 2013 Song Chen et al. This is an open access article distributed under the Creative Commons Attribution License, which permits unrestricted use, distribution, and reproduction in any medium, provided the original work is properly cited.

\begin{abstract}
The effects of night temperature on plant morphology and nitrogen accumulation were examined in rice (Oryza sativa L.) during vegetative growth. The results showed that the shoot biomass of the plants was greater at $27^{\circ} \mathrm{C}$ (high nighttime temperature, HNT) than at $22^{\circ} \mathrm{C}(\mathrm{CK})$. However, the increase in both shoot and root biomasses was not significant under $10 \mathrm{mg} \mathrm{N} / \mathrm{L}$. The shoot nitrogen concentrations were $16.1 \%$ and $16.7 \%$ higher in HNT than in CK under 160 and $40 \mathrm{mg}$ N/L. These results suggest that plant N uptake was enhanced under HNT; however, the positive effect might be limited by the N status of the plants. In addition, leaf area, plant height, root maximum length, root and shoot nitrogen concentrations, soluble leaf protein content, and soluble leaf carbohydrate content were greater in HNT than in CK under 40 and $160 \mathrm{mg} \mathrm{N} / \mathrm{L}$, while fresh root volume, root number, and the content of free amino acid in leaf were not significantly different between HNT and CK regardless of nitrogen levels. Moreover, leaf GS activity under HNT was increased at $160 \mathrm{mg} \mathrm{N} / \mathrm{L}$ compared with that under CK, which might partly explain the positive effect of HNT on soluble protein and carbohydrate content.
\end{abstract}

\section{Introduction}

High temperature stress is an important yield limiting factor in rice (Oryza sativa L.). The global average temperature has been increasing over the past 100 years and is projected to increase in the range of 1.4 to $5.8^{\circ} \mathrm{C}$ by the end of the twenty-first century at the present rates of greenhouse gas emissions and population growth [1]. In addition, climate models foresee that a relatively greater increase in nighttime temperatures than daytime temperatures will occur because of less radiant heat loss due to increased cloudiness [2]. Over the past century the increases in global daily minimum temperatures were more those twice that of daily maximum temperatures [3]. Evidence of historical yields of rice [4] and wheat [5] shows that cereal yield was strongly correlated with minimum nighttime temperatures rather than daytime maximum temperatures. For example, decreasing rice yields in the Philippines [4] and increasing wheat yields in Mexico [5] were related to increasing nighttime temperatures.

The influence of high temperatures on carbon and nitrogen metabolism in rice and other crops is well documented.
High temperatures damage photosynthetic membranes and cause chlorophyll loss [6], decrease leaf photosynthetic rate, increase embryo abortion [7], lower grain number, and decrease grain filling duration and rates [8-11], resulting in lower grain yield [10, 12-15]. On the other hand, photosynthetic capacity is closely associated with leaf nitrogen $[16,17]$. High $\mathrm{N}$ level enhances photosynthesis and delays senescence [18]. The two key enzymes involved in assimilating intracellular ammonium into organic compounds are glutamate dehydrogenase (GDH) and glutamine synthetase (GS), which also participate in photosynthesis and carbohydrate metabolism $[19,20]$. Heat stress will result in a decrease in leaf $\mathrm{N}$ content $[18,21]$ as well as GDH and GS activities $[20,22]$ because GDH and GS are associated with amino acid conversion [19] and amino acid composition might be altered due to heat stress, which could promote stress resistance [23]. However, most studies on the effects of high temperatures on crop plants have not differentiated between day- and nighttime temperature regimes.

Generally, crop development and growth rates and duration of critical phases can be differently sensitive to minimum 
and maximum temperatures [24]. High nighttime temperatures (HNT) are considered to be disadvantageous because they can stimulate respiration, thereby affecting yield [25]. HNT also affects the leaf photosynthetic rate [26-28], which is attributed to its indirect effects on leaf chlorophyll content [29], leaf area [30], leaf nitrogen concentration (LNC), and various enzymes involved in photosynthesis. Thereby, the effect of HNT on plant growth seems to be closely related with the changes of the coupled plant metabolisms, carbon and nitrogen assimilation. It has been suggested that better understanding of plant responses to HNT is needed to better quantify and reduce uncertainties in climate change impact assessments [24]. However, there has been very little study of the influence of HNT (at constant daytime temperature) on nitrogen and carbon metabolism of rice plants.

The objective of this study was to investigate the combined effects of different nighttime temperatures $\left(22^{\circ}\right.$ and $27^{\circ} \mathrm{C}$ ) and different nitrogen levels in hydroponic solution $(10,40$, and $160 \mathrm{mg} \mathrm{N} / \mathrm{L})$ imposed during the vegetative phase (transplanting to panicle initial stage) on dry matter production, plant nitrogen accumulation, and plant morphological traits under hydroponic solutions. We also investigated the effects of HNT on the content of soluble carbohydrate, soluble starch, soluble protein and free amino acid (FAA) concentration, and the activities of GS, GDH, GPT, and GOT in leaf. The main purpose of this study was to test whether the negative effect of increased nighttime temperature on plant growth could be alleviated by the nitrogen supply in the vegetative stage.

\section{Materials and Methods}

2.1. Plant Material, Growth, and Treatments. Rice (Oryza sativa L. cv. N2Y-6) plants were grown hydroponically for 54 days after germination. Seeds were soaked in tap water for 1 day and then germinated at $32^{\circ} \mathrm{C}$ for 2 days. The germinated seeds were broadcasted on the soil pot and grown in a greenhouse, with a $12 \mathrm{~h}$ photoperiod of $1000-1500 \mu \mathrm{mol}$ quanta $\mathrm{m}^{-2} \mathrm{~s}^{-1}$ of photosynthetic photon flux density (PPFD), 56$85 \%$ relative humidity, and an average day/night temperature regime of $33 / 23^{\circ} \mathrm{C}$ for 21 days. Seedlings with four leaves were transplanted to a basic nutrient hydroponics solution containing $2.9 \mathrm{mM} \mathrm{NH} \mathrm{NO}_{3}, 0.32 \mathrm{mM} \mathrm{NaH} \mathrm{PO}_{4}$, $1.0 \mathrm{mM} \mathrm{K}_{2} \mathrm{SO}_{4}, 1.0 \mathrm{mM} \mathrm{CaCl}_{2}, 1.7 \mathrm{mM} \mathrm{MgSO}_{4} \cdot 7 \mathrm{H}_{2} \mathrm{O}, 9.1 \mu \mathrm{M}$ $\mathrm{MnCl}_{2} \cdot 4 \mathrm{H}_{2} \mathrm{O}, 0.52 \mu \mathrm{M}\left(\mathrm{NH}_{4}\right)_{6} \mathrm{Mo}_{7} \mathrm{O}_{24} \cdot 4 \mathrm{H}_{2} \mathrm{O}, 18 \mu \mathrm{M} \mathrm{H}_{3} \mathrm{BO}_{3}$, $0.15 \mu \mathrm{M} \mathrm{ZnSO} \cdot 7 \mathrm{H}_{2} \mathrm{O}, 0.16 \mu \mathrm{M} \mathrm{CuSO}_{4} \cdot 5 \mathrm{H}_{2} \mathrm{O}$, and $36 \mu \mathrm{M}$ $\mathrm{FeCl}_{3} \cdot 6 \mathrm{H}_{2} \mathrm{O}$. The $\mathrm{pH}$ value of the solution was adjusted to 5.5 using $1 \mathrm{M} \mathrm{HCl}$ or $\mathrm{NaOH}$ solution as required [31]. Half concentration of the nutrient solution was applied for the first 3 days as pretreatment and then changed to the set nutrient solution. Nutrient solutions were renewed every four days.

A plastic pot (length $\times$ width $\times$ height: $40 \times 30 \times$ $30 \mathrm{~cm}$ ) was used, with seedlings planted on the foam and fixed by sponge. The planting spacing was $10 \times 10 \mathrm{~cm}$ with two seedlings per hill. Three pots with 36 hills were set as one replication. Four environmentally controlled growth chambers (PGB-400; Laifu, China) were used for one rice

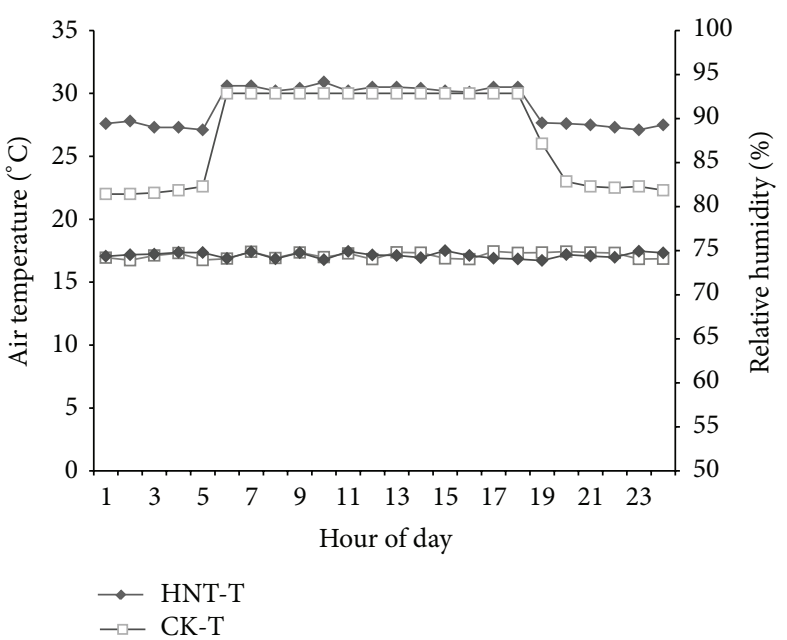

FIGURE 1: Changes in the air temperature and relative humidity over a day. Plants were grown under two different night temperatures (22 and $\left.27^{\circ} \mathrm{C}\right)$ and the same day temperature $\left(30^{\circ} \mathrm{C}\right)$.

variety, with two temperature treatments, three nitrogen treatments, and three replications.

After the pretreatment, the seedlings were transferred into solutions with different nitrogen concentrations: low (LN, $10 \mathrm{mg} \mathrm{N} / \mathrm{L})$, moderate (MN, $40 \mathrm{mmg} \mathrm{N} / \mathrm{LL})$, and high ( $\mathrm{HN}, 160 \mathrm{mg} \mathrm{N} / \mathrm{mL}$ ). A total of 18 plots with different nitrogen levels were planted. Two temperature treatments (day/night) were set as $\mathrm{HNT}\left(30^{\circ} \mathrm{C} / 27^{\circ} \mathrm{C}\right)$ and $\mathrm{CK}\left(30^{\circ} \mathrm{C} / 22^{\circ} \mathrm{C}\right)$. Daytime was from 05:00 to 18:00 with a PPFD of $1200 \mu \mathrm{mol}$ quanta $\mathrm{m}^{-2} \mathrm{~s}^{-1}$ and a relative humidity of $75 \%$ throughout the whole day. The details of air/water temperature and relative humidity over a day can be found in Figure 1.

2.2. Determination of Plant Biomass, Leaf Area, and Morphological Traits. Twelve plants from each replication were sampled at 54 days after germination. The plants were divided into shoot and root and oven-dried separately at $80^{\circ} \mathrm{C}$ until the dry weight was consistent. The plant height, maximum root length, and root number were measured manually. Root volume was equal to the volume increase of water in a graduated cylinder when the fresh root was submerged. Leaf area was measured using Licor3100C (LICOR, USA). Then, the dry weight was measured and plant tissues were ground into powder for further analysis. Additional 12 plants were sampled for chemical analysis. Fresh leaf and root were separated immediately and stored at $-20^{\circ} \mathrm{C}$ for further use.

2.3. Nitrogen Concentration, Soluble Protein, Soluble Free Amino Acid, and Soluble Carbohydrate and Starch. Total nitrogen concentration was determined with an autoanalyzer (Foss 2100, FOSS Kjeltec, USA) using the Kjeldahl method following vitriol digestion. Soluble protein content was determined by the protein-dye binding method introduced by Braford [32] using bovine serum albumin as the standard. Amino acid concentration in the leaf was determined by the Ninhydrin method [33] using L-leucine as the standard. 
TABLE 1: Night temperature effect on the plant height, maximum root length, root volume, root number, leaf area, and shoot and root dry weights of rice seedlings.

\begin{tabular}{|c|c|c|c|c|c|c|c|c|}
\hline Nitrogen level (N) & $\begin{array}{l}\text { Temp. } \\
(T)\end{array}$ & $\begin{array}{l}\text { Plant height } \\
(\mathrm{cm})\end{array}$ & $\begin{array}{l}\text { Maximum } \\
\text { root length } \\
(\mathrm{cm})\end{array}$ & $\begin{array}{l}\text { Root volume } \\
\left(\mathrm{cm}^{3} \text { plant }^{-1}\right)\end{array}$ & $\begin{array}{c}\text { Root } \\
\text { number } \\
\left(\text { plant }^{-1}\right) \\
\end{array}$ & $\begin{array}{c}\text { Leaf area } \\
\left(\mathrm{cm}^{2} \text { plant }^{-1}\right)\end{array}$ & $\begin{array}{c}\text { Shoot dry } \\
\text { weight (g/100 } \\
\text { plants) }\end{array}$ & $\begin{array}{l}\text { Root dry weight } \\
\text { (g/100 plants) }\end{array}$ \\
\hline \multirow{2}{*}{160} & $22^{\circ} \mathrm{C}$ & $42.87 \pm 1.49 b$ & $15.58 \pm 3.10 \mathrm{~b}$ & $0.92 \pm 0.08 \mathrm{a}$ & $92 \pm 16 a$ & $49.3 \pm 8.3 b$ & $5.82 \pm 0.20 \mathrm{~b}$ & $2.41 \pm 0.21 \mathrm{a}$ \\
\hline & $27^{\circ} \mathrm{C}$ & $45.53 \pm 1.06 \mathrm{a}$ & $17.38 \pm 3.75 b$ & $1.01 \pm 0.11 \mathrm{a}$ & $83 \pm 14 a$ & $55.9 \pm 6.8 \mathrm{a}$ & $6.40 \pm 0.28 \mathrm{a}$ & $2.20 \pm 0.19 \mathrm{a}$ \\
\hline \multirow{2}{*}{40} & $22^{\circ} \mathrm{C}$ & $39.88 \pm 2.43 b$ & $17.46 \pm 2.61 b$ & $0.82 \pm 0.14 \mathrm{ab}$ & $72 \pm 20 \mathrm{ab}$ & $42.8 \pm 3.6 c$ & $5.51 \pm 0.10 c$ & $2.23 \pm 0.15 a$ \\
\hline & $27^{\circ} \mathrm{C}$ & $44.33 \pm 1.82 \mathrm{a}$ & $20.58 \pm 2.56 \mathrm{ab}$ & $0.80 \pm 0.09 b$ & $85 \pm 18 \mathrm{ab}$ & $48.7 \pm 9.1 b$ & $6.01 \pm 0.19 b$ & $2.05 \pm 0.03 \mathrm{ab}$ \\
\hline \multirow{2}{*}{10} & $22^{\circ} \mathrm{C}$ & $40.71 \pm 1.65 b$ & $18.63 \pm 2.10 b$ & $0.75 \pm 0.13 b$ & $66 \pm 16 b$ & $35.3 \pm 3.6 \mathrm{~d}$ & $5.02 \pm 0.26 \mathrm{~d}$ & $1.97 \pm 0.11 b c$ \\
\hline & $27^{\circ} \mathrm{C}$ & $40.17 \pm 1.77 \mathrm{~b}$ & $23.99 \pm 2.46 a$ & $0.72 \pm 0.14 b$ & $56 \pm 12 b$ & $39.6 \pm 6.8 \mathrm{c}$ & $5.27 \pm 0.10 \mathrm{~d}$ & $1.68 \pm 0.01 c$ \\
\hline \multirow{3}{*}{ ANOVA } & $\mathrm{N}$ & $*$ & $* *$ & $* *$ & $* *$ & $* *$ & $* *$ & $* *$ \\
\hline & $T$ & $* *$ & $* *$ & ns & ns & ** & $* *$ & $* *$ \\
\hline & $\mathrm{N} * T$ & ns & ns & ns & ns & ns & ns & ns \\
\hline
\end{tabular}

Rice seedlings were grown under two different night temperatures of $22^{\circ} \mathrm{C}$ and $27^{\circ} \mathrm{C}$ with three nitrogen levels of $10 \mathrm{mg} \mathrm{N} / \mathrm{L}, 40 \mathrm{mg} \mathrm{N} / \mathrm{L}$, and $160 \mathrm{mg} \mathrm{N} / \mathrm{L}$. Values were expressed as means \pm standard error $(n=3)$, and the same small letter in the same column means that the values are not significantly different at $P<0.05$ by Tukey's HSD.

Soluble carbohydrates and starch were determined following the method of Zhu et al. [34] using sucrose as the standard.

2.4. GOT, GPT, GS, and GDH Activities. Glutamic-oxaloacetic transaminase (GOT) and glutamic-pyruvic transaminase (GPT) activity were assayed by the method of Wu et al. [35]; one unit (U) of activities was defined as the increase in pyruvic acid content per g protein per hour. Glutamine synthetase (GS) activity was assayed by the method of Spario and Stadtman [36]; one unit (U) of activity was defined as the increase in glutamylhydroxamate per g protein per hour. Glutamate dehydrogenase (GDH) activity was determined following the method of Zhang et al. [37]; one unit (U) of activity was defined as the increase in $\mathrm{NADH}$ per g protein per minute.

2.5. SOD, POD, CAT, and MDA. The activity of superoxide dismutase (SOD) was determined according to the method of Dhindsa et al. [38]. One unit of enzyme activity was taken as the activity to cause $50 \%$ inhibition. The nitroblue tetrazolium reduction rate was measured by monitoring the absorbance at $560 \mathrm{~nm}$. The activity of peroxidase (POD) was determined in a reaction solution composed of $50 \mathrm{mM}$ PBS (pH 7.0), $2 \mathrm{mM} \mathrm{H}_{2} \mathrm{O}_{2}, 2.7 \mathrm{mM}$ guaiacol, and $0.05 \mathrm{~mL}$ enzyme extract by monitoring the increase in absorbance at $470 \mathrm{~nm}$ due to guaiacol oxidation [39]. The activity of catalase (CAT) was assayed in accordance with the method of Jiang and Huang [40]. The malondialdehyde (MDA) content was determined by the method of Heath and Packer [41].

2.6. Data Analysis. The experiments were laid out in a complete randomized design and were repeated a total of three times. To test the significance of nighttime temperatures effect on growth development and physiology parameters, the data were statistically analyzed using two-way analysis of variance (ANOVA; SAS statistical analysis package version 9.0, SAS Institute, Cary, NC, USA). The means were separated using Tukey's HSD at $P<0.05$. The standard errors of the mean were also calculated and presented in the graphs as error bars.

\section{Results}

3.1. Morphological Characteristics. Four-leaf age seedlings were transplanted and exposed to $\operatorname{HNT}\left(27^{\circ} \mathrm{C}\right)$ at three nitrogen levels for about 33 days. Obvious symptoms of the nitrogen levels in rice seedling were observed. For example, there was a difference in plant height, and the leaves turned yellow in the low nitrogen level condition. To illustrate the effect of HNT on the morphological characteristics of rice seedlings, we determined the plant height, maximum root length, total number of roots, root volume, leaf area, and shoot and root dry weights (Table 1).

Generally speaking, all the morphological characteristics improved along with the nitrogen increase except for the maximum root length. The effect of HNT on morphological traits varied within nitrogen levels. Plant height, leaf area, and shoot dry weight were greater in $\mathrm{HNT}\left(27^{\circ} \mathrm{C}\right)$ than in $\mathrm{CK}\left(22^{\circ} \mathrm{C}\right)$ under the nitrogen level sof 160 and $40 \mathrm{mg} \mathrm{N} / \mathrm{L}$, but little difference was found with nitrogen of $10 \mathrm{mg} \mathrm{N} / \mathrm{L}$. The maximum root length in HNT was increased compared with that in CK in the low nitrogen level condition (10 mg N/L), but little difference was found in plants under 40 and $160 \mathrm{mg} \mathrm{N} / \mathrm{L}$. In comparison with $22^{\circ} \mathrm{C}$, plant height in $27^{\circ} \mathrm{C}$ was $11.1 \%$ and $6.2 \%$ higher under 40 and $160 \mathrm{mg} \mathrm{N} / \mathrm{L}$, respectively. The root length was $28.7 \%$ greater in $22^{\circ} \mathrm{C}$ than in $27^{\circ} \mathrm{C}$ at $10 \mathrm{mg} \mathrm{N} / \mathrm{L}$. There was little difference in root volume, root number, and root dry weight between HNT and CK.

\subsection{Nitrogen Concentration and Accumulation in Shoot and} Root. The HNT effect on nitrogen concentration and accumulation in shoot and root is shown in Figure 2.

Root nitrogen concentrations were $7.72 \%, 23.5 \%$, and $10.2 \%$ greater in HNT than in CK at 160,40 , and $10 \mathrm{mg} \mathrm{N} / \mathrm{L}$, respectively. Shoot nitrogen concentrations were $16.1 \%$ and 

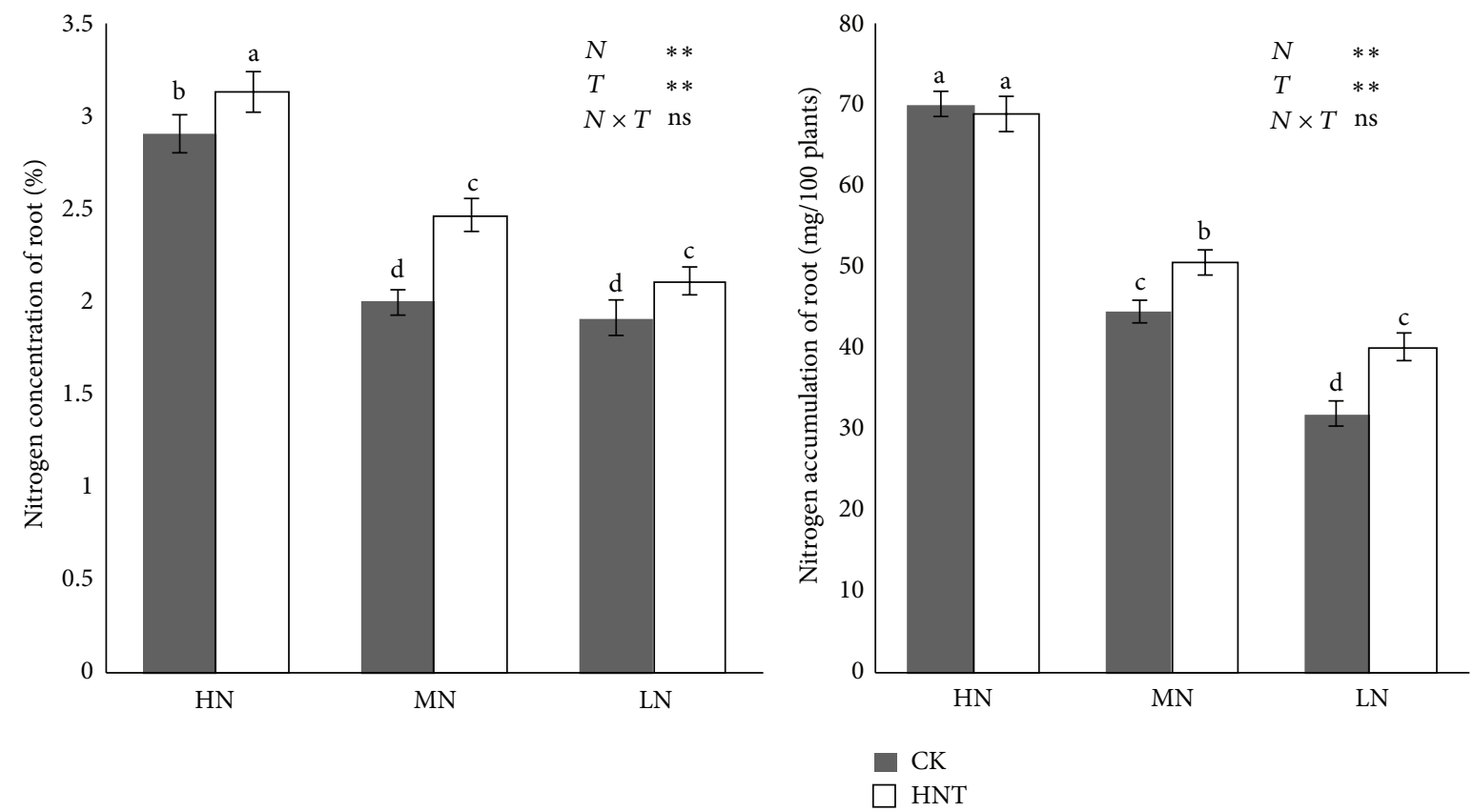

(a)

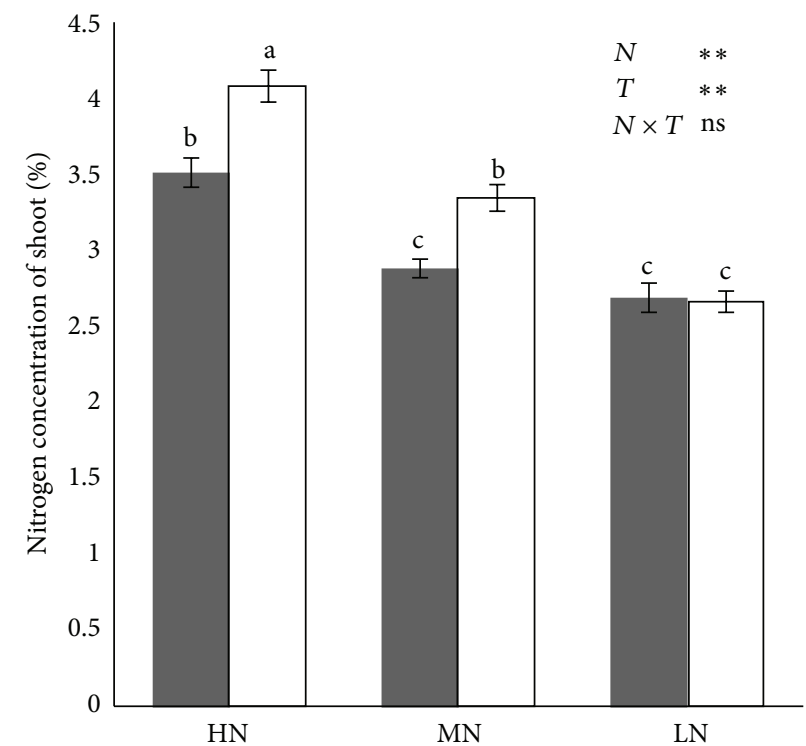

(c)

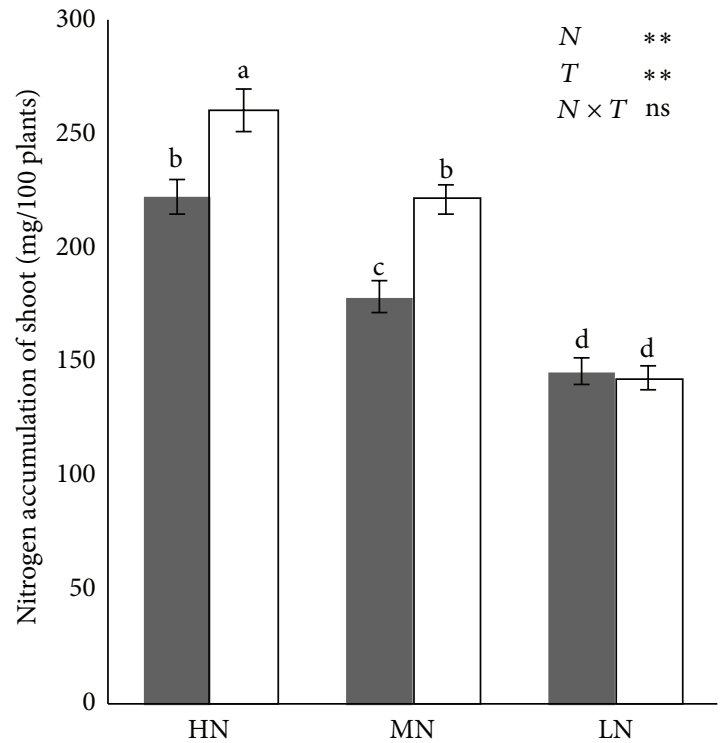

(d)

FIGURE 2: Nitrogen concentration and accumulation in the root and shoot of rice seedling ((a)-(d)). Plants were grown under two temperatures of $22^{\circ} \mathrm{C}(\mathrm{CK})$ and $27^{\circ} \mathrm{C}(\mathrm{HNT})$ with three nitrogen levels of $10 \mathrm{mg} \mathrm{N} / \mathrm{L}$ (low nitrogen level: LN), $40 \mathrm{mg}$ N/L (moderate nitrogen level: $\mathrm{MN}$ ), and $160 \mathrm{mg} \mathrm{N} / \mathrm{L}$ (high nitrogen level: HN). Range bars indicate the standard deviation $(n=3)$. ANOVA results are embedded in the figure: ns: not significant; ${ }^{* *} P<0.01$. Columns with the same letter are not significantly different at $P<0.05$ by Tukey's HSD.

$16.7 \%$ greater in HNT than in CK at 160 and $40 \mathrm{mg} \mathrm{N} / \mathrm{L}$, respectively, but little difference was found at $10 \mathrm{mg} \mathrm{N} / \mathrm{L}$. The effect of HNT on nitrogen accumulation and content was similar in root and shoot except that there was no significant difference in root nitrogen accumulation between HNT and $\mathrm{CK}$ in the high nitrogen condition (160 $\mathrm{mg} \mathrm{N} / \mathrm{L})$.
3.3. Leaf Soluble Protein, Free Amino Acid, and Soluble Carbohydrate Content. Metabolic productions of leaf nitrogen and carbohydrate metabolism (i.e., soluble protein, free amino acid, and soluble carbohydrates) were determined (Figure 3).

The results showed that there was no significant difference in leaf soluble protein content between CK and HNT at 40 


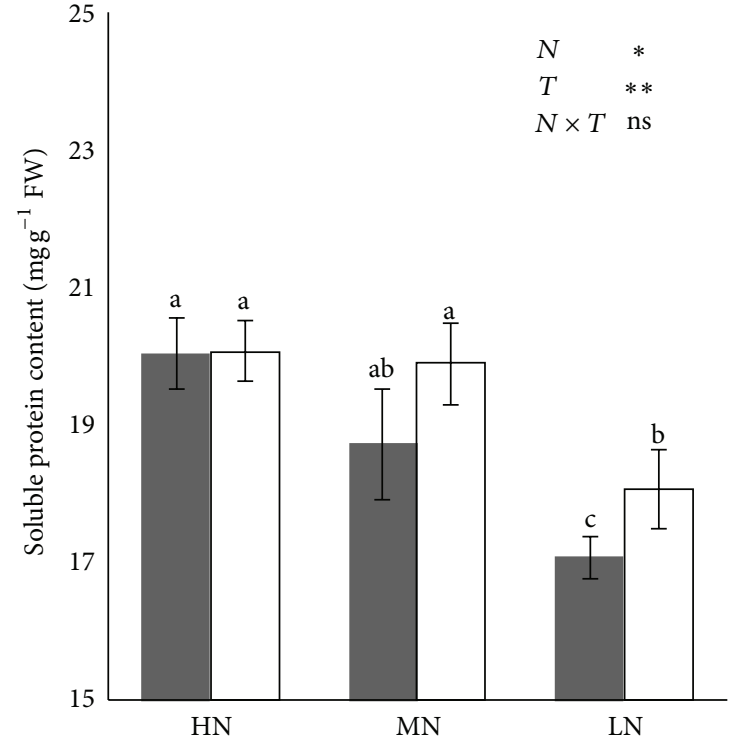

(a)

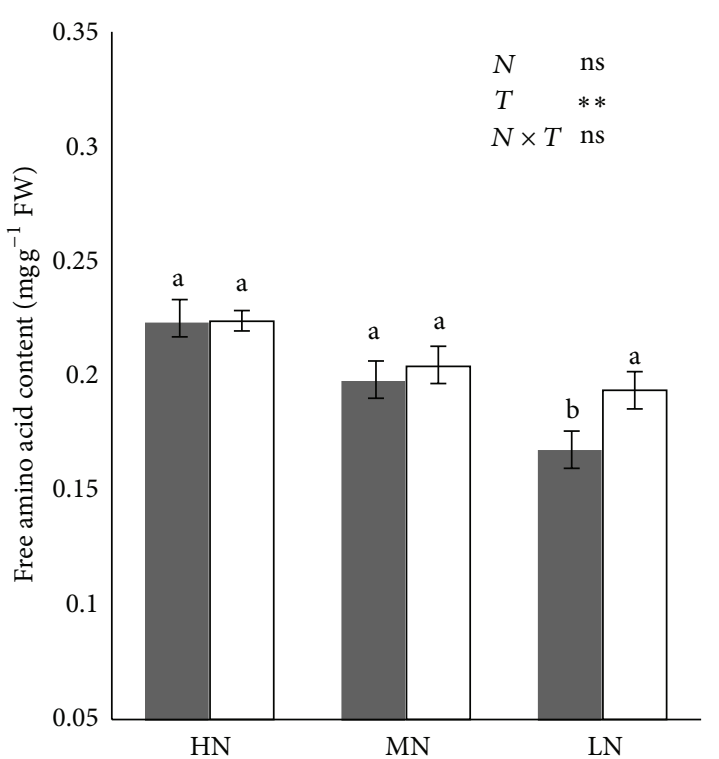

(b)

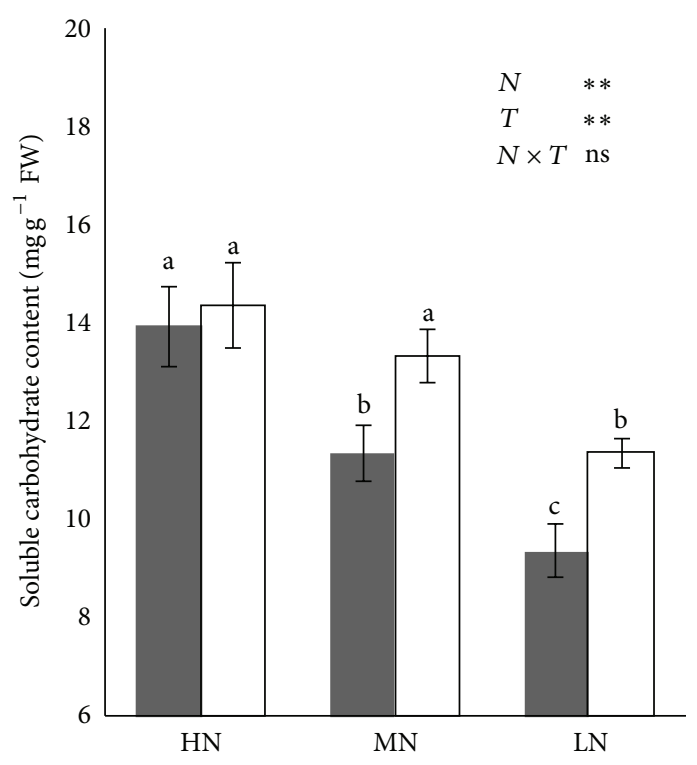

(c)

FIGURE 3: Leaf soluble proteins content (a), soluble sugar content (b), and free amino acid content (c) of rice seedling. Plants were grown under two temperatures of $22^{\circ} \mathrm{C}(\mathrm{CK})$ and $27^{\circ} \mathrm{C}(\mathrm{HNT})$ with three nitrogen levels of $10 \mathrm{mg} \mathrm{N} / \mathrm{L}(\mathrm{LN}), 40 \mathrm{mg} \mathrm{N} / \mathrm{L}(\mathrm{MN})$, and $160 \mathrm{mg} \mathrm{N} / \mathrm{L}$ (HN). Range bars indicate the standard deviation $(n=3)$. ANOVA results are embedded in the figure: ns: not significant; ${ }^{*} P<0.05 ;{ }^{* *} P<0.01$. Columns with the same letter are not significantly different at $P<0.05$ by Tukey's HSD.

and $160 \mathrm{mg} \mathrm{N} / \mathrm{L}$. However, a positive effect of HNT on leaf soluble protein content was significant at $10 \mathrm{mg} \mathrm{N} / \mathrm{L}$, being $5.8 \%$ greater in HNT than in CK. The effect of HNT on the leaf free amino acid and soluble carbohydrate content varied with $\mathrm{N}$ levels. The difference in leaf free amino acid and soluble carbohydrate content between CK and HNT was not significant at $160 \mathrm{mg} \mathrm{N} / \mathrm{L}$. A significant difference in soluble carbohydrate content was found at 40 and $10 \mathrm{mg} \mathrm{N} / \mathrm{L}$, with HNT being significantly greater than CK. A positive effect of HNT on free amino acid content was only observed at $10 \mathrm{mg} \mathrm{N} / \mathrm{L}$.
3.4. GOT, GPT, GS, and GDH Activities. Leaf GOT, GPT, GS, and GDH activities were determined to gain a better understanding of the nitrogen assimilation response to HNT (Figure 4). Leaf GOT activity in HNT was increased in the 10 and $160 \mathrm{mg} \mathrm{N} / \mathrm{L}$ conditions compared with CK, while the opposite results were found for leaf GPT. HNT effects on GS and GDH activities were altered by nitrogen levels. Leaf GS activity under HNT was increased at $160 \mathrm{mg} \mathrm{N} / \mathrm{L}$ and stayed consistent at $40 \mathrm{mg} \mathrm{N} / \mathrm{L}$, but decreased at $10 \mathrm{mg} \mathrm{N} / \mathrm{L}$ compared with that under CK. The effect of HNT on leaf GDH activity was the opposite at $160 \mathrm{mg} \mathrm{N} / \mathrm{L}$ but no 

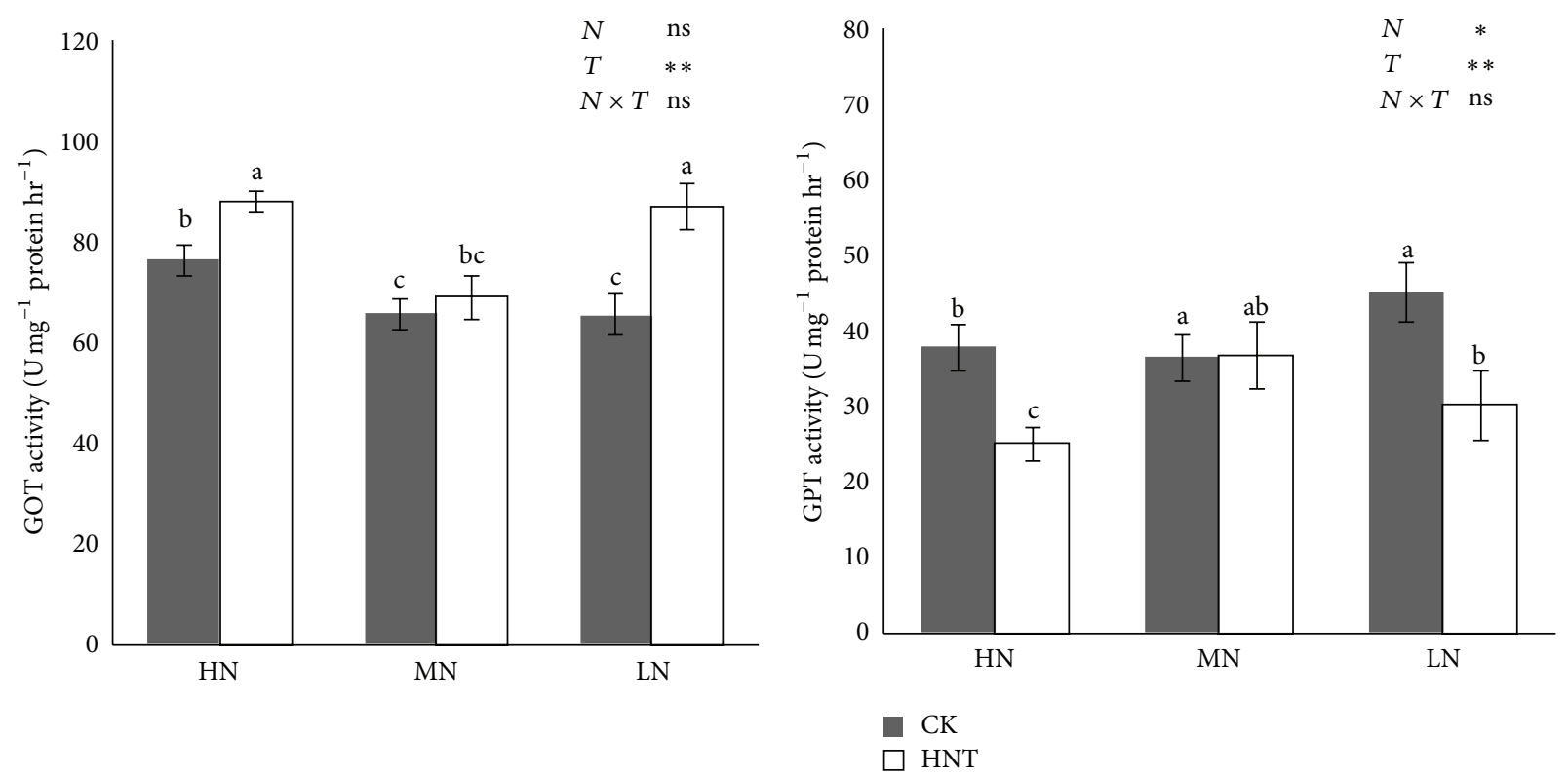

(a)

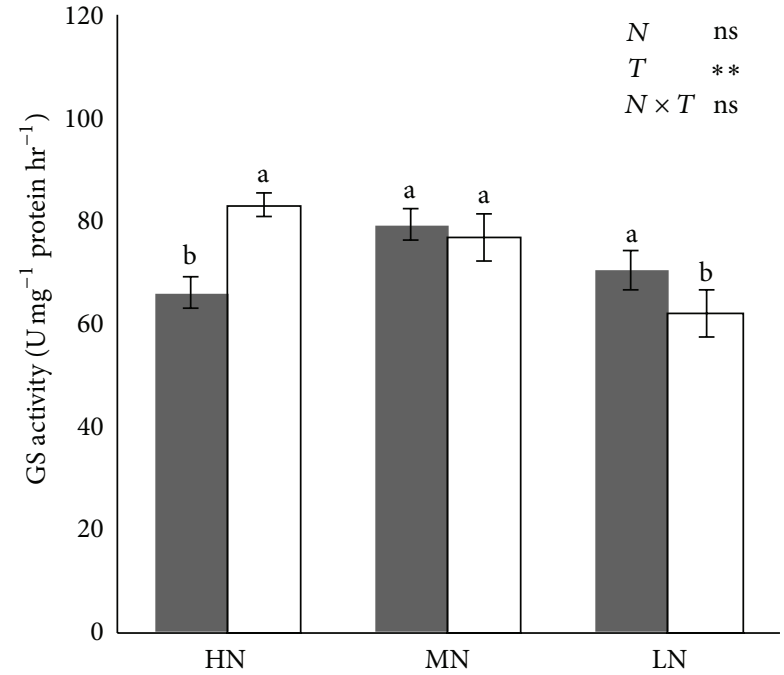

(c) (b)

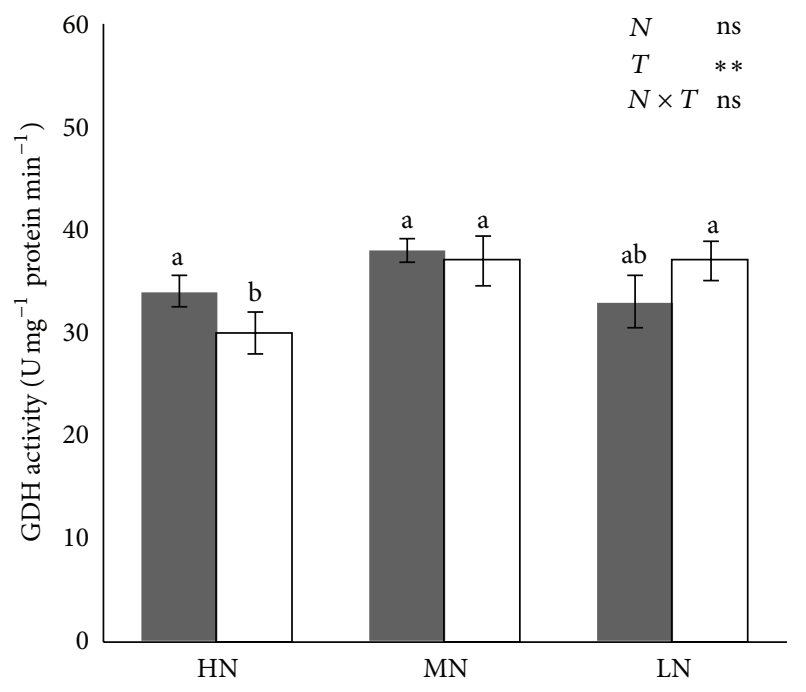

(d)

Figure 4: GOT (a), GPT (b), GS (c), and GDH (d) activities of rice seedling leaf. Plants were grown under two different temperatures of $22^{\circ} \mathrm{C}$ (CK) and $27^{\circ} \mathrm{C}(\mathrm{HNT})$ and three different nitrogen levels of $10 \mathrm{mg} \mathrm{N} / \mathrm{mL}(\mathrm{LN}), 40 \mathrm{mg} \mathrm{N} / \mathrm{mL}(\mathrm{MN})$, and $160 \mathrm{mg} \mathrm{N} / \mathrm{mL}$ (HN). Statistical analysis was carried out between temperature treatments using an ANOVA with Tukey's HSD. Columns with the same letter are not significantly different $(P<0.05)$.

significant difference was found at 40 and $10 \mathrm{mg} \mathrm{N} / \mathrm{L}$ between HNT and CK.

\section{Discussion}

4.1. High Nighttime Temperature Effect on Plant Biomass, Leaf, and Root Traits. A high temperature effect on plant biomass has been well documented. Morita et al. [42] found that high temperature accelerates the growth development, leading to decreased accumulation of photosynthates in the sheath, and promotes leaf area, thereby affecting the ultimate grain yield [42]. However, the effect of elevated nighttime temperature on plant biomass was just the opposite. Tanaka et al. [43] observed that biomass production increased with high nighttime water temperatures and that the leaf stage was also promoted. Hussey [44] found that elevated night temperatures in the range of $15-30^{\circ} \mathrm{C}$ contribute to an increase in the biomass production of tomato plants. Similar effects of night temperature were also found for Galega officinalis and Medicago sativa in the range of $4-25^{\circ} \mathrm{C}$, regardless of the daytime temperature [45]. In the current study, increased biomass under HNT was observed in the shoots of plant exposed to a nitrogen supply of 40 and $160 \mathrm{mg} \mathrm{N} / \mathrm{L}$, which was consistent with the previous reports. However, little 

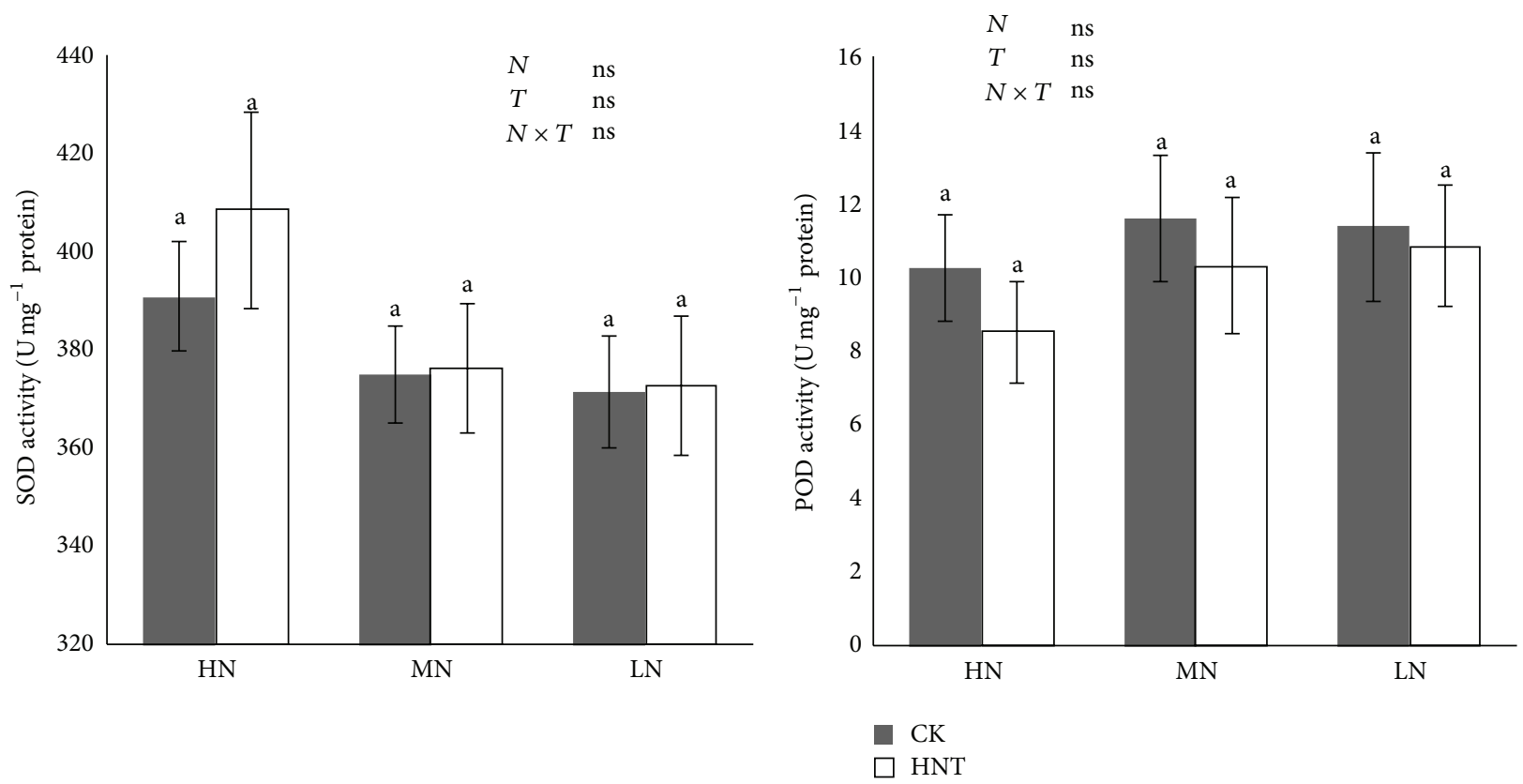

(a)
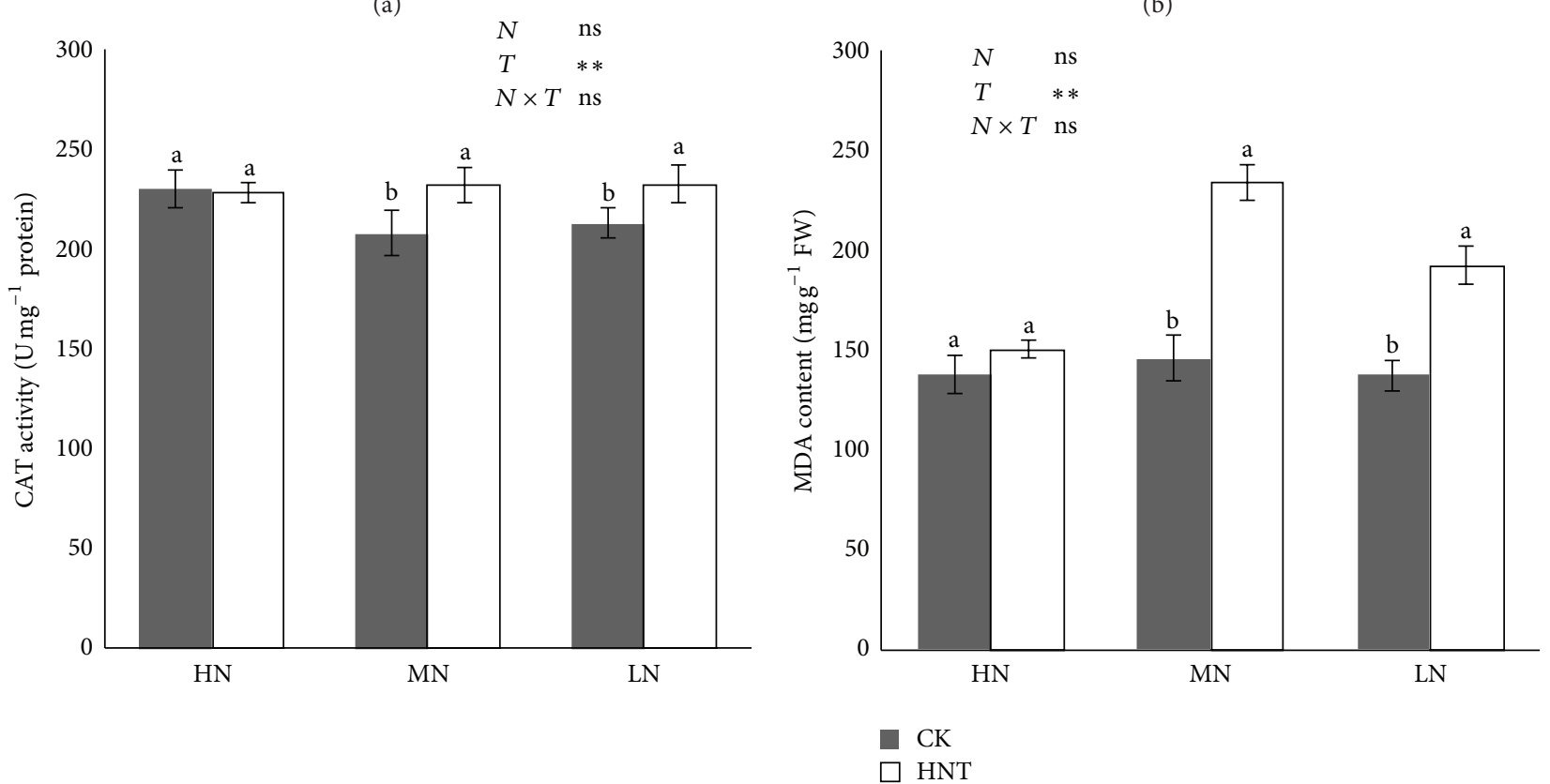

(c)

(d)

FIGURE 5: SOD, POD, and CAT activities and MDA ((a)-(d)) content of rice seedling leaf. Plants were grown under two different temperatures of $22^{\circ} \mathrm{C}(\mathrm{CK})$ and $27^{\circ} \mathrm{C}(\mathrm{HNT})$ and three different nitrogen levels of $10 \mathrm{mg} \mathrm{N} / \mathrm{mL}(\mathrm{LN}), 40 \mathrm{mg} \mathrm{N} / \mathrm{mL}(\mathrm{MN})$, and $160 \mathrm{mg} \mathrm{N} / \mathrm{mL}$ (HN). Statistical analysis was carried out between temperature treatments using an ANOVA with Tukey's test. Columns with the same letter are not significantly different $(P<0.05)$.

difference between HNT and CK was found in root biomass (Table 1).

Furthermore, leaf area was also promoted under HNT from $22^{\circ}$ to $27^{\circ} \mathrm{C}$. The increase in biomass production was attributed to an increase in leaf development. High night temperatures appear to stimulate cell division in the meristems of the leaf and might enlarge thinner leaves at the level of the single leaf [46]. On the other hand, Osone et al. [47] pointed out the importance of leaf-root interactions and found that the $\mathrm{N}$ absorption rate of the root was well correlated with leaf development. In this study, the increase in root biomass was not significant at $10 \mathrm{mg} \mathrm{N} / \mathrm{L}$, suggesting that $\mathrm{N}$ uptake is required to maintain a good correlation between leaf development and RGR under HNT.

High night temperature may also affect leaf or root traits during the vegetative stage and thus indirectly affect the grain 
yield [42]. Cutler et al. [48] stated that elevated night air temperature accelerates the leaf elongation of rice. Kanno et al. [49] found greater SLA in HNT plants, and Tsunoda [50] demonstrated that the leaf emergence rate increased when nighttime water temperatures increased. However, root traits were seldom reported. In the current research, we found that root biomass was not significantly different between $22^{\circ}$ and $27^{\circ} \mathrm{C}$, and similar results were found in fresh root volume and root number, regardless of the nitrogen level. We also found increased plant height, maximum root length, and leaf area in HNT $\left(27^{\circ} \mathrm{C}\right)$ compared with $\mathrm{CK}\left(22^{\circ} \mathrm{C}\right)$ for plants exposed to nitrogen levels of 160 and $40 \mathrm{mg} \mathrm{N} / \mathrm{L}$. The maximum root length in HNT was also increased compared with that in CK in the low nitrogen level condition (10 mg N/L), but little difference was found in plants under 40 and $160 \mathrm{mg} \mathrm{N} / \mathrm{L}$. These results suggest that the HNT effect on shoot and root development was not consistent during the vegetative stage.

4.2. High Nighttime Temperature on Rice N Metabolism. The effect of HNT on photosynthesis was attributed to its indirect effects on leaf chlorophyll content [29], leaf area [30], leaf nitrogen content (LNC), various enzymes involved in photosynthesis, or a combination of these factors. In this study, root and shoot nitrogen concentration and accumulation were analyzed. The root nitrogen concentrations were $7.72 \%$, $23.5 \%$, and $10.2 \%$ greater in HNT than in CK at 160, 40, and $10 \mathrm{mg} \mathrm{N} / \mathrm{L}$, respectively, while shoot nitrogen concentrations were $16.1 \%$ and $16.7 \%$ greater in HNT than in CK at 160 and $40 \mathrm{mg} \mathrm{N} / \mathrm{L}$, respectively. Similar results were found for nitrogen accumulation (Figure 2).

These results indicate that plant $\mathrm{N}$ uptake was enhanced under elevated nighttime temperature, similar to findings for spring wheat [51]. Leaf nitrogen plays a key role in carbohydrate assimilation and protein synthesis [52]. In the present study, high nighttime temperature increased leaf soluble carbohydrate content at 10 and $40 \mathrm{mg} \mathrm{N} / \mathrm{L}$ and soluble protein content and free amino acid at $10 \mathrm{mgN} / \mathrm{L}$ (Figure 3). However, differences in leaf soluble protein content, free amino acid content, and soluble carbohydrate content between HNT and CK were not significant at $160 \mathrm{mg} \mathrm{N} / \mathrm{L}$. It may be that increased accumulation of nitrogen under HNT conditions is related to the $\mathrm{N}$ supply level. Increases in the level of proteins or free amino acids were the result of the overall activities of protein synthesis which, in turn, may have an impact on plant nitrogen response or physiological tolerance to high temperatures [53].

The key enzymes involved in assimilating intracellular ammonium into organic compounds are glutamine synthetase (GS) and glutamate dehydrogenase (GDH). GS plays an essential role in the metabolism of nitrogen by catalyzing the condensation of glutamate and ammonia to form glutamine [54], while GDH converts glutamate to $\alpha$ ketoglutarate. Both enzymes participate in photosynthesis and carbohydrate metabolism $[19,20]$. Although a high $\mathrm{N}$ level enhances photosynthesis and delays senescence [18], high temperature results in a decrease in leaf $\mathrm{N}$ content $[18,21]$ and GS and GDH activities $[20,22]$. This is important because GDH and GS can be associated with amino acid conversion [19], and amino acid composition might be altered due to heat, which could promote stress resistance [23]. In the present research, the HNT effect on GS and GDH activities was altered by nitrogen levels. Leaf GS activity under HNT increased at $160 \mathrm{mg} \mathrm{N} / \mathrm{L}$ and remained consistent at $40 \mathrm{mg} \mathrm{N} / \mathrm{L}$ but decreased at $10 \mathrm{mg} \mathrm{N} / \mathrm{L}$ compared with that under CK. The effect of HNT on leaf GDH activity was opposite at $160 \mathrm{mg} \mathrm{N} / \mathrm{L}$, and no significant difference was found at 40 and $10 \mathrm{mg} \mathrm{N} / \mathrm{L}$ between HNT and CK. Further studies are needed to investigate the mechanism or mechanisms of the action of GS and GDH and its possible relation to HNT.

As an environmental stress, HNT might enhance leaf senescence, involving protein degradation, such as Rubisco [55]. Reactive oxygen species (ROS) production (i.e., superoxide dismutase (SOD), catalase (CAT), peroxide dismutase (POD), and malondialdehyde (MDA)) has the strongest correlation with resistance to oxidative stress. In the present study, no significant difference was found in SOD and POD between CK and HNT regardless of nitrogen levels. However, plants exposed to HNT were significantly greater in MDA and CAT than in $\mathrm{CK}$ at 40 and $10 \mathrm{mg} \mathrm{N} / \mathrm{L}$ (Figure 5). These results indicate that HNT stress on plants was slight, especially when the $\mathrm{N}$ supply was sufficient. However, the rice seedlings' defense mechanisms could be stimulated when the $\mathrm{N}$ supply is limited, which will, in turn, affect the nitrogen accumulation.

\section{Acknowledgments}

This research was partly supported by grants from the Zhejiang Province Natural Science Foundation of China (LQ12C13001), MOA Special Fund for Agro-Scientific Research in the Public Interest of China (201203096), and the earmarked fund from the China Agriculture Research System (CARS-01-27).

\section{References}

[1] IPCC, "Intergovernmental Panel on Climate Change," 2007.

[2] R. D. Alward, J. K. Detling, and D. G. Milchunas, "Grassland vegetation changes and nocturnal global warming," Science, vol. 283, no. 5399, pp. 229-231, 1999.

[3] D. R. Easterling, B. Horton, P. D. Jones et al., "Maximum and minimum temperature trends for the globe," Science, vol. 277, no. 5324, pp. 364-367, 1997.

[4] S. Peng, J. Huang, J. E. Sheehy et al., "Rice yields decline with higher night temperature from global warming," Proceedings of the National Academy of Sciences of the United States of America, vol. 101, no. 27, pp. 9971-9975, 2004.

[5] D. B. Lobell, J. I. Ortiz-Monasterio, G. P. Asner, P. A. Matson, R. L. Naylor, and W. P. Falcon, "Analysis of wheat yield and climatic trends in Mexico," Field Crops Research, vol. 94, no. 2-3, pp. 250256, 2005.

[6] K. Al-Khatib and G. M. Paulsen, "Mode of high temperature injury to wheat during grain development," Physiologia Plantarum, vol. 61, pp. 363-368, 1984.

[7] H. S. Saini, M. Sedgley, and D. Aspinall, "Effect of heat stress during floral development on pollen tube growth and ovary 
anatomy in wheat (Triticum aestivum L.)," Australian Journal of Plant Physiology, vol. 10, no. 2, pp. 137-144, 1983.

[8] I. F. Wardlaw and L. Moncur, "The responsse of wheat to high temperature following anthesis. I. The rate and duration of kernel filling," Australian Journal of Plant Physiology, vol. 22, no. 3, pp. 391-397, 1995.

[9] T. R. Wheeler, T. D. Hong, R. H. Ellis, G. R. Batts, J. I. L. Morison, and P. Hadley, "The duration and rate of grain growth, and harvest index, of wheat (Triticum aestivum L.) in response to temperature and $\mathrm{CO}_{2}$," Journal of Experimental Botany, vol. 47, no. 298, pp. 623-630, 1996.

[10] R. Ferris, R. H. Ellis, T. R. Wheeler, and P. Hadley, "Effect of high temperature stress at anthesis on grain yield and biomass of field-grown crops of wheat," Annals of Botany, vol. 82, no. 5, pp. 631-639, 1998.

[11] P. V. V. Prasad, K. J. Boote, L. H. Allen Jr., J. E. Sheehy, and J. M. G. Thomas, "Species, ecotype and cultivar differences in spikelet fertility and harvest index of rice in response to high temperature stress," Field Crops Research, vol. 95, no. 2-3, pp. 398-411, 2006.

[12] I. Wardlaw, I. Dawson, and P. Munibi, "The tolerance of wheat to high temperatures during reproductive growth. 2. Grain development," Crop \& Pasture Science, vol. 40, pp. 15-24, 1989.

[13] P. Stone and M. Nicolas, "Wheat cultivars vary widely in their responses of grain yield and quality to short periods of postanthesis heat stress," Functional Plant Biology, vol. 21, pp. 887900, 1994.

[14] T. R. Wheeler, G. R. Batts, R. H. Ellis, P. Hadley, and J. I. L. Morison, "Growth and yield of winter wheat (Triticum aestivum) crops in response to $\mathrm{CO}_{2}$ and temperature," Journal of Agricultural Science, vol. 127, no. 1, pp. 37-48, 1996.

[15] L. R. Gibson and G. M. Paulsen, "Yield components of wheat grown under high temperature stress during reproductive growth," Crop Science, vol. 39, no. 6, pp. 1841-1846, 1999.

[16] T. Mae, "Physiological nitrogen efficiency in rice: nitrogen utilization, photosynthesis, and yield potential," Plant and Soil, vol. 196, no. 2, pp. 201-210, 1997.

[17] L. Llorens, J. Peñuelas, and I. Filella, "Diurnal and seasonal variations in the photosynthetic performance and water relations of two co-occurring Mediterranean shrubs, Erica multiflora and Globularia alypum," Physiologia Plantarum, vol. 118, no. 1, pp. 84-95, 2003.

[18] T. R. Sinclair, P. J. Pinter Jr., B. A. Kimball et al., "Leaf nitrogen concentration of wheat subjected to elevated $\left[\mathrm{CO}_{2}\right]$ and either water or N deficits," Agriculture, Ecosystems and Environment, vol. 79, no. 1, pp. 53-60, 2000.

[19] H.-M. Lam, K. T. Coschigano, I. C. Oliveira, R. Melo-Oliveira, and G. M. Coruzzi, "The molecular-genetics of nitrogen assimilation into amino acids in higher plants," Annual Review of Plant Physiology and Plant Molecular Biology, vol. 47, no. 1, pp. 569593, 1996.

[20] R. Sibout and G. Guerrier, "Solute incompatibility with glutamine synthetase in water-stressed," Environmental and Experimental Botany, vol. 40, pp. 173-178, 1998.

[21] L. Llorens, J. Peñuelas, and M. Estiarte, "Ecophysiological responses of two Mediterranean shrubs, Erica multiflora and Globularia alypum, to experimentally drier and warmer conditions," Physiologia Plantarum, vol. 119, no. 2, pp. 231-243, 2003.

[22] G. K. Abd-El Baki, F. Siefritz, H.-M. Man, H. Weiner, R. Kaldenhoff, and W. M. Kaiser, "Nitrate reductase in Zea mays L. under salinity," Plant, Cell and Environment, vol. 23, no. 5, pp. 515-521, 2000.
[23] L. Rizhsky, H. Liang, J. Shuman, V. Shulaev, S. Davletova, and R. Mittler, "When defense pathways collide. The response of arabidopsis to a combination of drought and heat stress," Plant Physiology, vol. 134, no. 4, pp. 1683-1696, 2004.

[24] D. B. Lobell and J. I. Ortiz-Monasterio, "Impacts of day versus night temperatures on spring wheat yields: a comparison of empirical and CERES model predictions in three locations," Agronomy Journal, vol. 99, no. 2, pp. 469-477, 2007.

[25] S. Zheng, H. Nakamoto, K. Yoshikawa, T. Furuya, and M. Fukuyama, "Influences of high night temperature on flowering and pod setting in soybean," Plant Production Science, vol. 5, no. 3, pp. 215-218, 2002.

[26] L. R. Gibson and R. E. Mullen, "Influence of day and night temperature on soybean seed yield," Crop Science, vol. 36, no. 1, pp. 98-104, 1996.

[27] M. H. Turnbull, R. Murthy, and K. L. Griffin, "The relative impacts of daytime and night-time warming on photosynthetic capacity in Populus deltoides," Plant, Cell and Environment, vol. 25, no. 12, pp. 1729-1737, 2002.

[28] J. M. Frantz, N. N. Cometti, and B. Bugbee, "Night temperature has a minimal effect on respiration and growth in rapidly growing plants," Annals of Botany, vol. 94, no. 1, pp. 155-166, 2004.

[29] I. M. Vågen, R. Moe, and E. Ronglan, "Diurnal temperature alternations (DIF/drop) affect chlorophyll content and chlorophyll a/chlorophyll b ratio in Melissa officinalis L. and Ocimum basilicum L., but not in Viola $\times$ wittrockiana Gams.," Scientia Horticulturae, vol. 97, no. 2, pp. 153-162, 2003.

[30] J. F. Thomas and C. D. Raper, "Effect of day and night temperatures during floral induction on morphology of soybeans," Agronomy Journal, vol. 70, pp. 893-898, 1978.

[31] S. Yoshida, Fundamentals of Rice Crop Science, International Rice Research Institute, 1981.

[32] M. M. Bradford, "A rapid and sensitive method for the quantitation of microgram quantities of protein utilizing the principle of protein-dye binding," Analytical Biochemistry, vol. 72, no. 1, pp. 248-254, 1976.

[33] S. Moore and W. H. Stein, "A modified ninhydrin reagent for the photometric determination of amino acids and related compounds," The Journal of Biological Chemistry, vol. 211, no. 2, pp. 907-913, 1954.

[34] C. Zhu, J. Zhu, Q. Zeng, G. Liu et al., "Elevated $\mathrm{CO}_{2}$ accelerates flag leaf senescence in wheat due to ear photosynthesis which causes greater ear nitrogen sink capacity and ear carbon sink limitation," Functional Plant Biology, vol. 36, pp. 291-299, 2009.

[35] L. H. Wu, S. H. Jiang, and Q. N. Tao, "Colorimetric method for plant transaminase (GOT and GPT activity)," Chinese Journal Of Soil Science, vol. 29, pp. 136-138, 1998.

[36] B. M. Shapiro and E. R. Stadtman, "Glutamine synthetase (Escherichia coli)," Methods in Enzymology, vol. 17, pp. 910-922, 1970.

[37] C. Zhang, S. Peng, X. Peng, A. Q. Chavez, and J. Bennett, "Response of glutamine synthetase isoforms to nitrogen sources in rice (Oryza sativa L.) roots," Plant Science, vol. 125, no. 2, pp. 163-170, 1997.

[38] R. S. Dhindsa, P. Plumb-dhindsa, and T. A. Thorpe, "Leaf senescence: correlated with increased levels of membrane permeability and lipid peroxidation, and decreased levels of superoxide dismutase and catalase," Journal of Experimental Botany, vol. 32, no. 1, pp. 93-101, 1981. 
[39] A. Polle, T. Otter, and F. Seifert, "Apoplastic peroxidases and lignification in needles of Norway spruce (Picea abies L.)," Plant Physiology, vol. 106, no. 1, pp. 53-60, 1994.

[40] Y. Jiang and B. Huang, "Drought and heat stress injury to two cool-season turfgrasses in relation to antioxidant metabolism and lipid peroxidation," Crop Science, vol. 41, no. 2, pp. 436-442, 2001.

[41] R. L. Heath and L. Packer, "Photoperoxidation in isolated chloroplasts. I. Kinetics and stoichiometry of fatty acid peroxidation," Archives of Biochemistry and Biophysics, vol. 125, no. 1, pp. 189-198, 1968.

[42] S. Morita, J. Yonemaru, and J. Takanashi, "Grain growth and endosperm cell size under high night temperatures in rice (Oryza sativa L.)," Annals of Botany, vol. 95, no. 4, pp. 695-701, 2005.

[43] T. Tanaka, S. Matsushima, and T. Tomita, "Analysis of yield determining process and its application to yield-prediction and culture improvement of lowland rice. Lxxxiv. Effects of the different combinations of day- and night-water temperatures on the growth of rice seedlings," Proceedings of the Crop Science Society of Japan, vol. 37, pp. 187-193, 1968.

[44] G. Hussey, "Growth and development in the young tomato: III. The effect of night and day temperatures on vegetative growth," Journal of Experimental Botany, vol. 16, no. 3, pp. 373-385, 1965.

[45] D. T. Patterson, "Effects of day and night temperature on goatsrue (Galega officinalis) and alfalfa (Medicago sativa) growth," Weed Science, vol. 41, pp. 38-45, 1993.

[46] O. K. Atkin, I. Scheurwater, and T. Pons, "High thermal acclimation potential of both photosynthesis and respiration in two lowland Plantago species in contrast to an alpine congeneric," Global Change Biology, vol. 12, no. 3, pp. 500-515, 2006.

[47] Y. Osone, A. Ishida, and M. Tateno, "Correlation between relative growth rate and specific leaf area requires associations of specific leaf area with nitrogen absorption rate of roots," New Phytologist, vol. 179, no. 2, pp. 417-427, 2008.

[48] J. M. Cutler, P. L. Steponkus, M. J. Wach et al., "Dynamic aspects and enhancement of leaf elongation in rice," Plant Physiology, vol. 66, no. 1, pp. 147-152, 1980.

[49] K. Kanno, T. Mae, and A. Makino, "High night temperature stimulates photosynthesis, biomass production and growth during the vegetative stage of rice plants," Soil Science and Plant Nutrition, vol. 55, no. 1, pp. 124-131, 2009.

[50] K. Tsunoda, "Studies on the effects of water-temperature on the growth and yield in rice plants," Bulletin of the National Institute of Agricultural Sciences A, vol. 11, pp. 75-174, 1964.

[51] P. V. V. Prasad, S. R. Pisipati, Z. Ristic, U. Bukovnik, and A. K. Fritz, "Impact of nighttime temperature on physiology and growth of spring wheat," Crop Science, vol. 48, no. 6, pp. 23722380, 2008.

[52] B. Riis, S. I. S. Rattan, B. F. C. Clark, and W. C. Merrick, "Eukaryotic protein elongation factors," Trends in Biochemical Sciences, vol. 15, no. 11, pp. 420-424, 1990.

[53] T. Moriarty, R. West, G. Small, D. Rao, and Z. Ristic, "Heterologous expression of maize chloroplast protein synthesis elongation factor (EF-Tu) enhances Escherichia coli viability under heat stress," Plant Science, vol. 163, no. 6, pp. 1075-1082, 2002.

[54] D. Eisenberg, H. S. Gill, G. M. U. Pfluegl, and S. H. Rotstein, "Structure-function relationships of glutamine synthetasesre," Biochimica et Biophysica Acta, vol. 1477, no. 1-2, pp. 122-145, 2000.
[55] C. Jiang, K. Ishihara, K. Satoh, and S. Katoh, "Loss of the photosynthetic capacity and proteins in senescing leaves at top positions of two cultivars of rice in relation to the source capacities of the leaves for carbon and nitrogen," Plant and Cell Physiology, vol. 40, no. 5, pp. 496-503, 1999. 

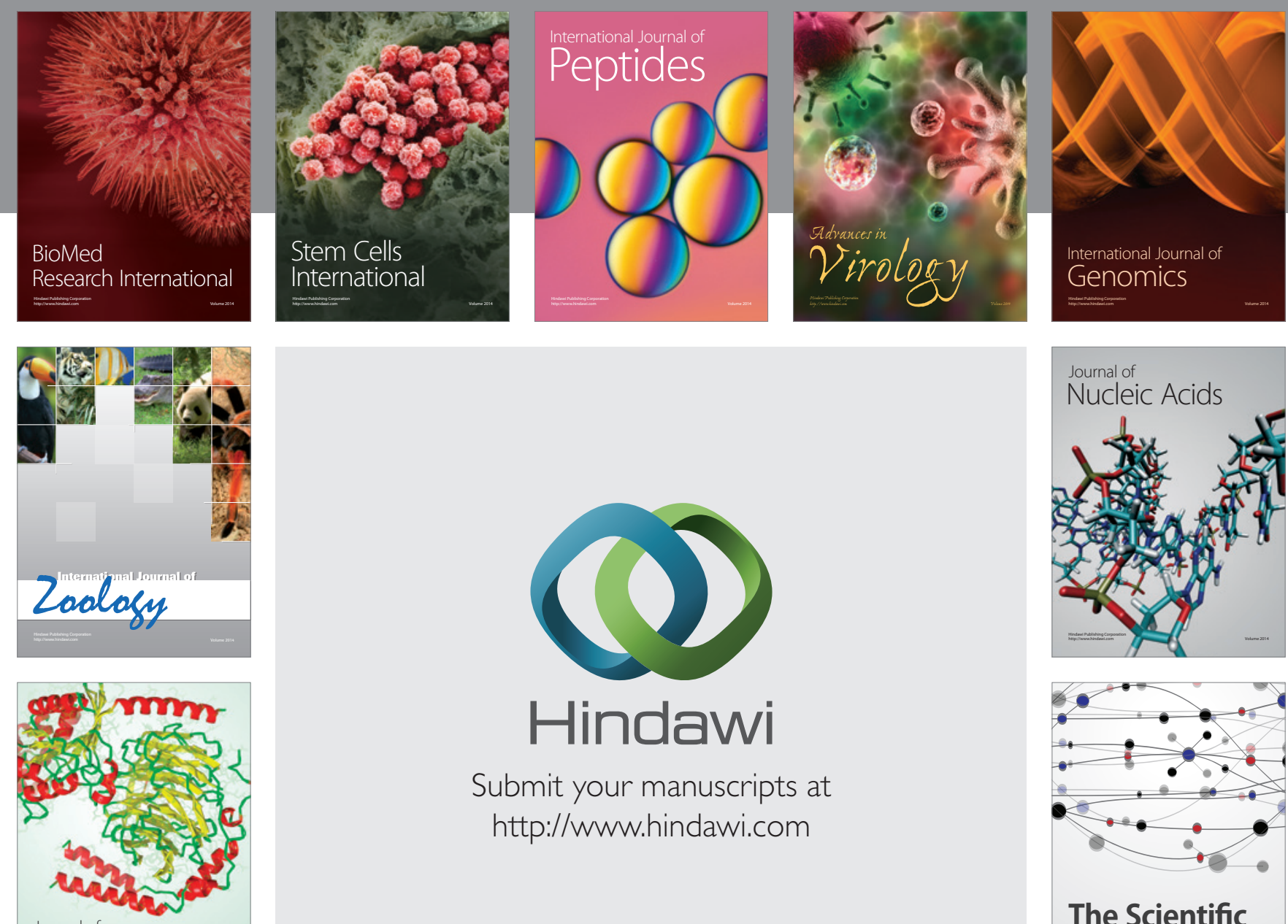

Submit your manuscripts at

http://www.hindawi.com

Journal of
Signal Transduction
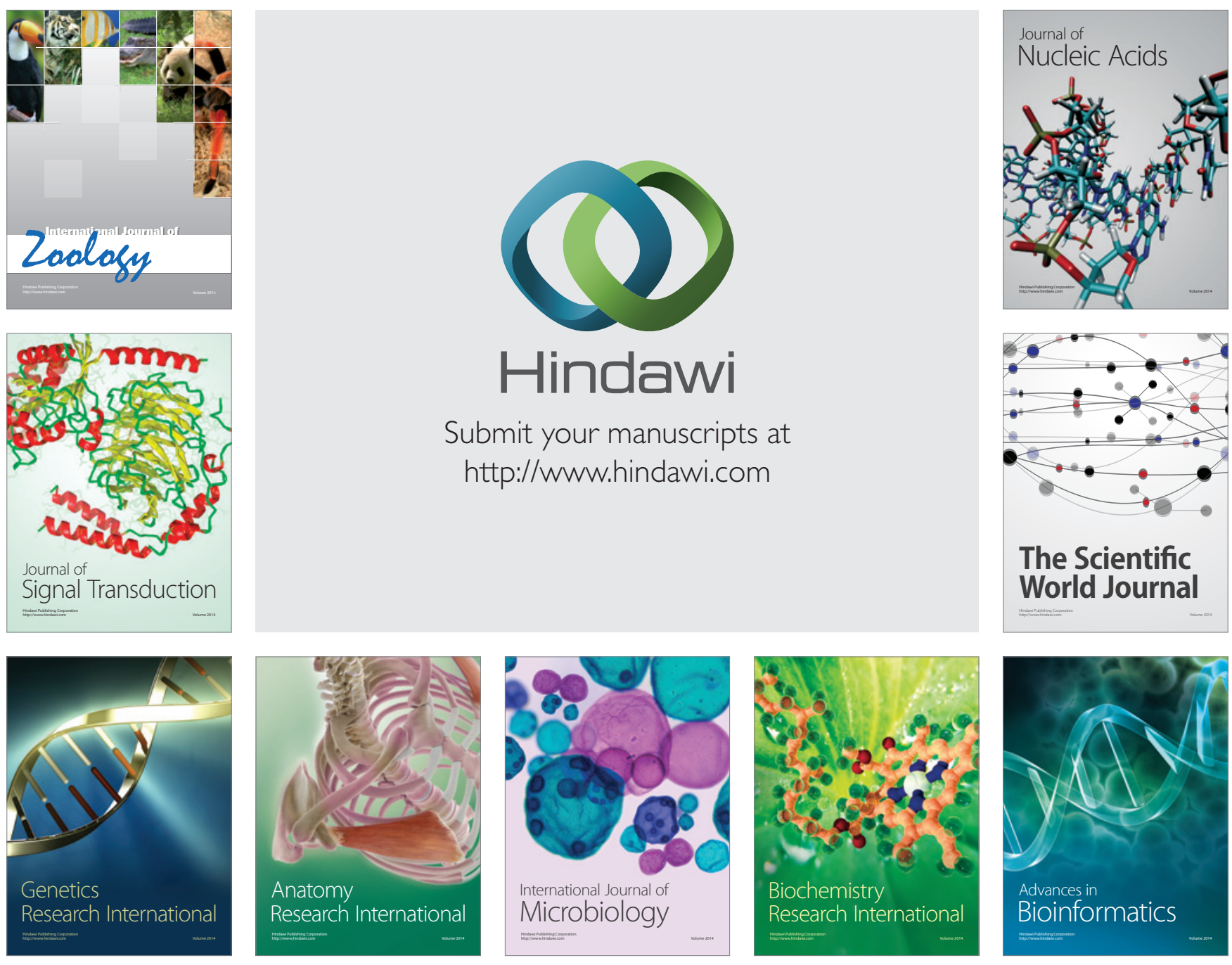

The Scientific World Journal
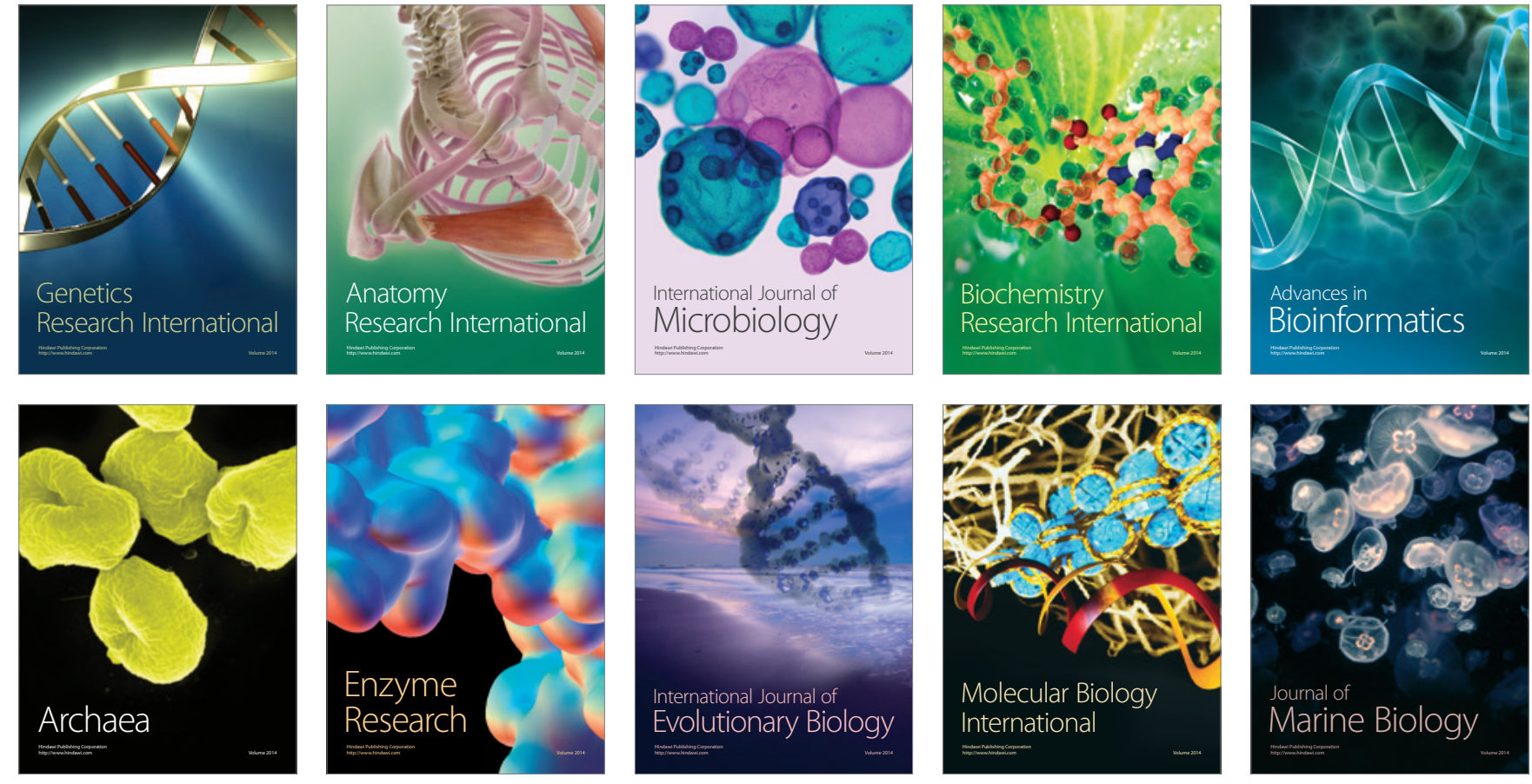